\author{
高岸 徹
}

\title{
Recent Studies on Liposomes
}

\author{
Toru Takagishi
}

\section{1. 緒 言}

生体膜の構成成分である脂質によって形成される二分 子膜に团孔れ，内部に水層を有する閉鎖小胞はリポソー ムまたはベシクルとよばれ，界面活性剤の形成するミセ ルと異なって比較的安定に存在することから, 各方面で その利用が注目されている。最近, 特に楽学, 医学, 工 学, 農学関係に和いてその応用が期待されている。

薬学関係に和いては，ドラッグデリバリーシステム (DDS, 薬物送達システム) と関連して, 特に関心がは らわれている。DDS とは薬物の生体への適用方法に和 いて, 有效性, 安全性, 信頼性に関して最も高い保証を 与えるように，薬物投与の最適化をはかることを目的と する新しい投与システムであり ${ }^{11}$ ，薬物投与に伴う種々 の問題, 例光ば疼痛, 面倒さ, 飲み忘れ, 反復大量投与に 伴ら副作用，感染などを少しでも軽減しようとして開発 されたものである。リポソームは医薬品以外に化粧品に 対しても応用され，既に製品は市場に出されている2゙。 化粧品に応用されつつあるリポソームの最近の動向につ いては, 鈴木, 左近られによって詳しく紹介されてい る。また, リポソームは食品, 塗料, 農薬への応用る研 究されている。

リポソームは種々の長所と可能性をもっているが, 実 用化には克服しなければならない問題も数多く残されて いる。

本稿では, リポソームに関する最近の研究動向, 特に 高度に機能化されたりポソーム和よび脂質膜被覆マイク 口カプセルを中心にして, 最近の研究を紹介するととも に，その問題点を述べてみたい。

大阪府立大学工学部応用化学科：堺市百舌鳥梅町 4 Department of Applied Chemistry, University of Osaka Prefecture: Mozu-Umemachi 4, Sakai, Osaka 591, Japan

\section{2.リポソームの特性}

リポソームには次の1)〜8)のよらな特性がある。

1）天然の脂質を用いるため生体適合性があり，細胞 膜と親和性がある

2）親水性・蹯水性部分から構成されているため，親 水性・蹯水性物質を取り达もことができる

3）脂質成分として代謝される

4) 生体内で特異的分布挙動をする

5）表面電荷を変えることができる

6）粒子径を変えることができる

7）脂質成分を変えたり、コレステロールなどの添加 によって，膜の硬さ，膜流動性を変えることがで きる

8）膜内外の $\mathrm{pH}$ を変えることができる

リポソームは特に 1)，2），3）の特性のために，ドラ ッグキャリャーとしての観点からよく研究されて和り, 最近ではさらに高度の機能をもたせることが盛んに行わ れている。その一つはリポソームに組織, 細胞特異性を 付与する,すなわら特定組織, 細胞へのターゲッティン グ (標的指向性) であり，もら一つはリリースコントロ 一ル(薬物徐放) である。ターゲッティングに関して は，5），6），7）の特性をコントロールすることによる受 動的標的指向性の他に，ターゲッティングをさらに積極 的, 高度に行う, 能動的標的指向性の観点からの研究が 最近注目されている。このよらな高度に機能化されたり ポソームは，医薬のみならず化粧品の分野に物いてb， 今後ますます重要になってくるものと思われる。

また、リリースコントロールを指向したアプローチも ある。リポソームは界面活性剂の形成するミセルに比べ ると安定であるが，膜中の脂質分子間には共有結合が形 成されていないために，物理的，化学的に弱い構造であ り，とれを補強する目的执よびリリースコントロールを より高度化する，なおち外部刺激に対してすばやく応 
答し，物質透過をコントロールする目的から，マイクロ カプセルへの脂質の被覆化が注目されてきている。この よらな被覆化によって生体適合性も得られる。光（紫外 線), 熱, $\mathrm{pH}$ などによって応答する脂質膜被覆化マイク ロカプセルは，化粧品への応用子可能になるのではない かと考光られる。湿度, 水分に対しても応答可能なら ば，保湿機能と関連して化粧品としてさらに有効性は増 すであらら。

\section{3.リポソームの調製法}

リポソームの調製法としては，次のような方法が試み られている。代表的な方法をあげるど，

1）ガラスビーズかくはん (Vortexing) 法

2）超音波法

3）コール酸（界面活性剤）除去法

4) 逆相蒸発 (REV, Reverse Phase Evaporation)法

5) 有機溶媒（エタノール，エーテル）注入法

6) フレンチプレス法

7) $\mathrm{Ca}^{2+}$ 融合法

8）クロロホルムーエーテル小球法

9）光重合法

これらの方法によって得られるリポソーム(ベシクル) の種類は異なる。すなわち, 大きな一枚膜りポソーム (LUV), 多重層りポソーム (MLV), 小さな一枚膜りポ ソーム (SUV) の 3 種類であり, 調製法によって形成さ れるベシクルの種類は異なってくる。また, リポソーム 内部に封入物質を入れる場合，Fig.-1 に示すような方 法によって行うことができる。封入物質としては, 薬剤 はもとよりホルモン, 酵素, 遺伝子, タンパク質, 生体

\section{リポソーム調製法}

脂質組成 (リン脂質, コレステロール等)／有機溶媒 有機溶媒除去

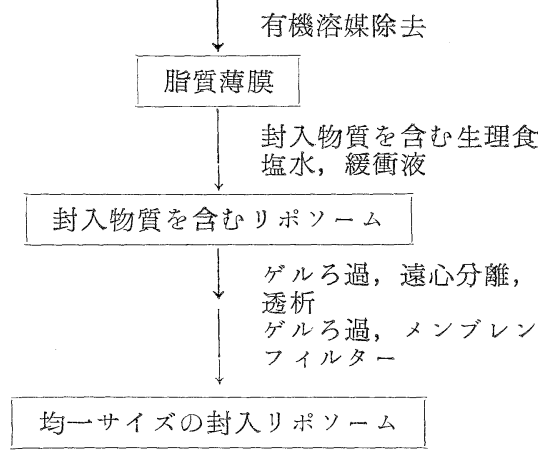

Fig.-1 Preparation of liposome
高分子, ビタミン, ウイルス, 塩類, キレート剤等低分 子から高分子にわたって，種々の物質を封入することが 可能でめる。その場合に封入物質の分子量とベシクルの サイズは関係し，高分子量の物質は SUV には内包でき ない。

最近化粧品に和いても, ビタミン C, E, コラーゲン, エラスチン，ヒアルロン酸，ソルブルコラーゲン，プラ センタ，リン酸ーLーアスコルビルマグネシウム， $\gamma$-才 リザノール, UVフラビン, 牛血清除タンパク抽出物など を内包したりポソームを配合することが試みられてい る2)

一定脂質量当たり保持できる内水層の体積を保持容積 といい，仕込んだ溶質の量に対してリポソームに保持さ れた溶質量をトラップ効率といらが，保持容積，トラッ プ効率ともに LUV が一番大きくSUVが最も小さい。

\section{4. リポソームと細胞との相互作用}

リポソームが細胞と相互作用する場合，リポソームを 形成する脂質組成，脂質の表面荷電，ベシクルのサイ ズ，膜の流動性，2 価カチオン $\left(\mathrm{Ca}^{2+}, \mathrm{Mg}^{2+}\right.$ など)の 存在などによって様式は異なってくる。すなおち,

1) エンドサイトシス

2) 融合

3) 吸着

4）膜構成成分の交換反応

などがある4。このうち特に重要であるのが1)叔よび2） の機構である。1)は中性物質で硬い（ゲル状態）リポソ ームで物こり，2）は正または負の荷電をもつ脂質で軟ら かい，流動性の大きい液晶状態のリポソームで起こると いわれている。3)の場合, 細胞膜などの特定吸着座席と 相互作用する特異的吸着と，そうでない非特異的吸着が ある。

リポソーム配合化粧品では，表皮および真皮に稀いて 1)が起こる可能性は非常に小さく，2）, 3)の可能性が大 さいものと推定される。リポソーム配合化粧品では，活 性物質を内包したりポソームが皮膚表面に到達した際， 皮膚界面に括いてリポソームの吸着あるいは崩壞をへ て, リポソーム自体は経皮吸収されることなく, 内包活 性物質を表皮に放出することにより，活性物質濃度の増 大をもたらすとともに，活性物質の吸収量を高めるとい う作用機構が示唆されている5)。実際, ${ }^{14} \mathrm{C}$-ジパルミト イルホスファチジルコリンでは, 皮膚投与部位に ${ }^{14} \mathrm{C}$ 活 性がみられるのみで，体内への移行は認められないが， ${ }^{14} \mathrm{C}$-ブチルパラベンは経皮吸収後体内移行するといら結 
果が報告されている5゙。

リポソームの皮膚表面に拈ける挙動は化粧品に和いて 非常に重要であるが，それを推定するための一助とし $\tau$, lipid mixing, content mixing, content leakage について詳しく説明する6) 9)。融合機構はケイ光物質の ケイ光強度扣よび消化によって調べられている。二つの 方法があり，ホスファチジルエタノールアミン (PE)な どのへッドグループにケイ光物質を共有結合させる方法 と，ケイ光物質叔よび消光物質をリポソーム中に取り込 ませて測定する方法である。Fig.-2に示すように lipid mixingでは，N-NBD 和よび N-Rh を化学修飾した PE からリポソームを形成させとのケイ光を測定すると, NNBD-PE を励起した場合, そのエネルギーは膜構成成 分として近傍に存在する N-Rh-PEに容易に移動し, NRh-PE の発光スペクトルが観測される。このよらなリ ポソームを他のリポソームと融合すると, lipid mixing の結果 N-NBD-PE と N-Rh-PEほ分離され, N-NBD$\mathrm{PE}$ の励起エネルギーは N-Rh-PE に容易にエネルギー 移動できなくなり，N-Rh-PE の発光スペクトル強度は 減少し, N-NBD-PE の発光スペクトル強度が増大す る。このようにして, lipid mixing が起こったことがわ かる。

しかしながら, lipid mixing しても必ずしも content mixing しているとは限らない。そこで content mixing の測定法として，次のような方法が行われている。すな わら, ケイ光物質 (ANTS) と消光物質 (DPX) をそれ ぞれ別個のリポソーム中に封入する。融合前はANTSを 励起するとANTSの発光が見られるが，DPXの封入さ れたりポソームと融合すると, 融合リポソーム中では ANTS と DPX は塩を形成し, ANTS のケイ光は消光 される。このようにして, ANTS 特よびDPXをそれぞ れ含もリポソームが融合した結果, content mixing が 起こっていることがわかる。

また、リポソーム中に封入された物質は必ずしも内部 に留まっているとは限らないで, リポソーム系中から外 部へ漏孔てくる可能性もある。これを content leakage という。測定方法としては, ANTS とDPXを同一リポ ソーム中に封入して和くと, ANTS は DPX と結合する ことによって消光され発光スペクトルは観測されない が，封入物質である ANTS 叔よび DPX がリポソーム 内部から外部に漏れると，バルク中に ANTS DPXが 存在することになり、その結果 ANTS と DPXは離秃て 存在する確率が増大し, そのため ANTS の発光スペク トルが認められるようになる。このような方法によって
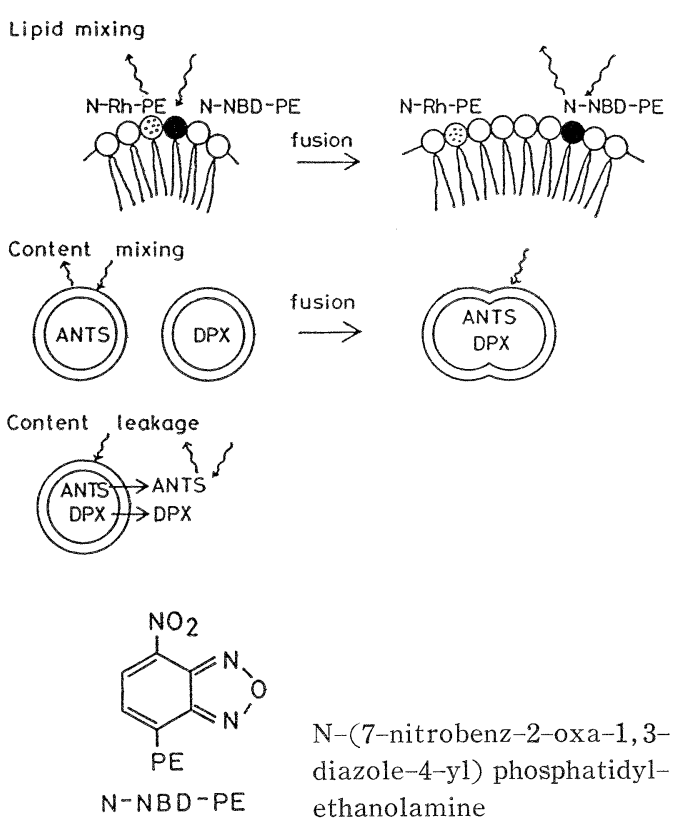<smiles>CCN(CC)c1ccc2c(-c3ccc(S(=O)(=O)OC)cc3[S-])c3ccc(=[N+](CC)CC)cc-3oc2c1</smiles>

$\mathrm{N}$-(lissamine Rhodamin B sulfonyl) phosphatidylethanolamine<smiles>Nc1cc(S(=O)(=O)O[Na])c2cc(S(=O)(=O)O[Na])cc(S(=O)(=O)O[Na])c2c1</smiles>

1-amino-3, 6,8-naphthalenetrisulfonie acid

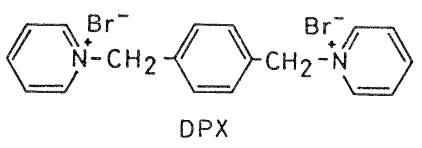

$\mathrm{N}, \mathrm{N}^{\prime}$-p-xylylene-bis (pyridinium bromide)

Fig.-2 Schematic drawing of fusion (lipid mixing, content mixing, and content leakage)

測定して得られた，融合におよぼす $\mathrm{Ca}^{2+}, \mathrm{Mg}^{2+}$ の效果 をTable-1に示す9?。の表から明らかなよらに, $\mathrm{Mg}^{2+}$ 
Table-1 Effects of divalent-cations on the interactions of DEPS/DEPE (Analogue) vesicles

\begin{tabular}{|c|c|c|c|c|c|c|c|c|c|}
\hline \multirow{2}{*}{ 中性脂質成分 } & \multirow{2}{*}{$\begin{array}{l}\mathrm{Ca}^{2+} \\
\text { 己心值 } \\
(\mathrm{mM})\end{array}$} & \multicolumn{3}{|c|}{$\mathrm{Ca}^{2+}$ 添加 } & \multirow{2}{*}{$\begin{array}{l}\mathrm{Mg}^{2+} \\
\text { 己きい值 } \\
(\mathrm{mM})\end{array}$} & \multicolumn{3}{|c|}{$\mathrm{Mg}^{2+}$ 添加 } & \multirow{2}{*}{$\mathrm{T}_{\mathrm{H}}\left({ }^{\circ} \mathrm{C}\right)^{\mathrm{a}}$} \\
\hline & & $\begin{array}{l}\text { lipid } \\
\text { mixing }\end{array}$ & $\begin{array}{c}\text { contents } \\
\text { mixing }\end{array}$ & leakage & & $\begin{array}{l}\text { lipid } \\
\text { mixing }\end{array}$ & $\begin{array}{c}\text { contents } \\
\text { mixing }\end{array}$ & leakage & \\
\hline DEPE & 1.7 & 107 & 32.6 & 3.2 & 3.0 & 76 & 14.1 & 1.7 & 63.5 \\
\hline DEPP . & 2.0 & 143 & 15.1 & 0.9 & 3.5 & 93 & 6.5 & 0.46 & 88.5 \\
\hline DEPB & 2.0 & 152 & 9.3 & 0.45 & 4.2 & 89 & 6.4 & 0.14 & $>95$ \\
\hline$N$-Methy1 DEPE & 7.0 & 160 & 15.6 & 1.45 & 11.0 & 118 & 5.3 & 0.24 & $>95$ \\
\hline$N$-Ethyl DEPE & 18.2 & 54.1 & 52.1 & 1.35 & 23 & 28.7 & 5.2 & 0.06 & $>95$ \\
\hline C-2-Methyl DEPE & 4.0 & 267 & 47.7 & 24 & 7.3 & 179 & 18.9 & 5.2 & 57.5 \\
\hline C-2-Dimethy1 DEPE & 5.0 & 181 & 145 & 78 & 9.5 & 158 & 70 & 39 & 55.5 \\
\hline C-2-Ethyl DEPE & 4.8 & 175 & 181 & 23 & 9.5 & 180 & 242 & 10 & $<47.8$ \\
\hline C-2-Isopropyl DEPE & 4.0 & 122 & 122 & 73 & 7.0 & 200 & 162 & 67 & $<62.0$ \\
\hline Dipalmitelaidoy1 PE & 1.9 & 154 & 10.6 & 1.75 & 3.0 & 143 & 8.1 & 0.45 & 92.5 \\
\hline
\end{tabular}

a ラメラーヘキサゴナル II 転移温度

$$
\begin{aligned}
& \text { DEPE Dielaidoylphosphatidylethanolamine } \\
& \mathrm{PE} \quad-\mathrm{O}-\mathrm{CH}_{2}-\mathrm{CH}_{2}-\stackrel{+}{\mathrm{N}} \mathrm{H}_{3} \\
& \mathrm{PP} \quad-\mathrm{O}-\mathrm{CH}_{2}-\mathrm{CH}_{2}-\mathrm{CH}_{2}-\stackrel{+}{\mathrm{N}} \mathrm{H}_{3} \\
& \mathrm{~PB} \quad-\mathrm{O}-\mathrm{CH}_{2}-\mathrm{CH}_{2}-\mathrm{CH}_{2}-\mathrm{CH}_{2}-\stackrel{+}{\mathrm{N}} \mathrm{H}_{3} \\
& N \text {-Methyl PE } \quad-\mathrm{O}-\mathrm{CH}_{2}-\mathrm{CH}_{2}-\stackrel{+}{\mathrm{N}} \mathrm{H}_{2}-\mathrm{CH}_{3} \\
& N \text {-Ethyl PE } \quad-\mathrm{O}-\mathrm{CH}_{2}-\mathrm{CH}_{2}-\stackrel{+}{\mathrm{N}} \mathrm{H}_{2}-\mathrm{CH}_{2}-\mathrm{CH}_{3} \\
& \text { C-2-Methyl PE }-\mathrm{O}-\mathrm{CH}_{2}-{\underset{\mathrm{CH}}{\mathrm{C}}}_{3}^{\mathrm{CH}}-\stackrel{+}{\mathrm{N}} \mathrm{H}_{3} \\
& \text { C-2-Dimethyl PE } \\
& \text { C-2-Ethyl PE } \\
& \text { C-2-Isopropyl PE }
\end{aligned}
$$
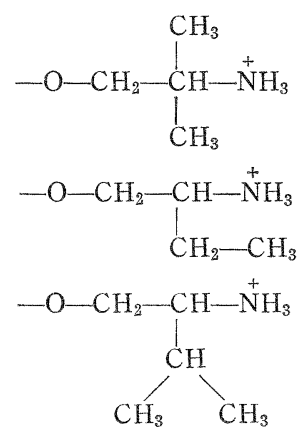

よりも $\mathrm{Ca}^{2+}$ の方がしきい值（融合が起こりほじめる添 加イオン濃度）が小さい。また，リポソームを構成する 脂質のヘッドグループの化学構造によって, lipid mixing, content mixing, content leakage の值がかなり 異なり，C-2-Dimethyl DEPE，C-2-Isopropyl DEPE のように, バルキーなへッドグループをもつ脂質では, 封入物質の leakage がかなり起こることがわかる。

\section{5. リポソームへの分子認識機能の付与}

先にも触れたよらに、リポソームの機能化が近年盛ん に行われている。その一つにリポソームへの標的指向性 の付与がある。指向性も受動的指向性から能動的指向性 に研究方向は進んでいる ${ }^{100}$ 。前者は，単純な脂質特よび コレステロールから形成されるリポソームのサイズ，コ 
レステロール含量, 脂質の化学構造, 表面の電荷状態な どを変えることによって，リポソームの構造特性を変 え，これらの変化が組織分布に影響を拈よぼすことを利 用して，目的とする組織てリポソームが集中的に相互作 用するように，上記因子を変えて標的指向性を出とうと するものである。一方後者は, 標的とする細胞表面のり セプターや決定因子を特異的に認識するリガンドを，リ ポソームの表面修飾する方法である。例光ば，抗原一 抗体反応の極めて高い,特異性を利用する方法，和よび糖 鎖が細胞の認識機能をるっていることを利用しようとす るものである。すなわち，

1）天然由来または合成糖脂質を利用する

2）膜糖タンパクを用いて再構成する

3）多糖誘導体によってリポソーム表面を被覆する

4）抗体などのりガンドを二重層膜中に組み込む

5）抗原または抗体（またはとのフラグメント）を共 有結合した脂質を利用する

6）リポソーム表面を被覆している多糖またはタンパ クへ抗原または抗体を共有結合させる などが進められている11。

一例として, デキストラン, プルラン, アミノペクチ ン, アミロース，マンナンなどにコレステロール，長鎖 アルキル基などを結合させ，これらをリポソーム中に組 又込むことによって, リポソーム外水層全体を多糖類で 被覆する研究が行われている100。委た，こ机らの多糖類 にモノクロナル抗体を結合させ，さらに細胞認識性を高 める試みもなさ机ている12)。しかしこのよらに抗体また はそのフラグメントを化学修飾することによって，リポ ソーム全体の生体適合性も悪くなるといら結果も出され て招り, 細胞認識性と生体適合性を両立させるように分 子設計することが今後重要な課題になる。

\section{6. リポソームの安定性, 保存性}

リポソームを種々の目的に用いる場合に, 物理的, 化 学的安定性招上び保存性が重要な因子になる。リポソー 么配合化粧品に招いても，長期保存性が大きな問題にな る。すなわち，

1）脂質の化学的安定性

2） サイズ，構造の安定性和よび保持

3）トラップした封入物質の保持

4）生体成分から受ける影響榇よびそれ対する安定 性

などである。特に2)に関しては、リポソームを形成する 脂質間には共有結合が存在しないため, サイズ, 構造の
保持は劣る。その対策として、リポソームを多糖類で被 覆し構造強化させる方法が考觉られている11。ここは植 物細胞, 細菌では細胞膜の外側にセルロース, ポリグル カンの細胞壁が存在し, 細胞を安定させていることによ る。おた，合成二分子膜と関連して，脂質の踈水基また は親水基中に重合基を導入して，膜形成と同時に隣り合 う脂質間飞共有結合を形成させ，膜構造を安定化させる 研究も行わ机ている13)。

\section{7. 外部刺激による内包物放出のコントロール}

リポソームをドラッグキャリヤーとして用い，目的の 細胞へ移行したのち内包物を放出する際, 外部刺激によ ってその放出をコントロールすることができれば，有効 性はさらに増大寸る。外部刺激としては, 温度, $\mathrm{pH}$, 光, 磁場, 電場, 超音波などが岁る。

\section{1 温度によるコントロール}

リポソームはゲルー液晶相転移を技こす。構成する脂 質の種類, 添加するコレステロール含量, 荷電物質など の存在によって, 相転移温度 $(\mathrm{Tc})$ は変化する。例光ば, 脂肪酸残基のアルキル基が長く, 不飽和度の低い脂質の Tc は高温になる。ホスファチジルコリンではジミリス トイル, ジパルミトイル，ジステアロイルとアルキル基 が長くなると，Tc $24 ， 41,58^{\circ} \mathrm{C}$ と高くなり,アル キル基の炭素数が同じでも, 不飽和度の大きいジオレオ イルでは Tcは $-22^{\circ} \mathrm{C}$ に低下する。

この現象を利用して, ジパルミトイルホスファチジル コリン $\left(\mathrm{Tc}=41^{\circ} \mathrm{C}\right)$ のリポソーム内部に制ガン剤を内包 させて, 温度感受性をもつ制ガン郕保持リポソームの温 熱療法が試みられている14)。体温ではこのリポソームは ゲル状態であり，内包物で西る制ガン剤は放出されない が， $41^{\circ} \mathrm{C}$ 以上飞昇温すると相転移が起こって液晶状態 になり，制がン剂は容易に放出されて効果が現れる。

\section{$7.2 \mathrm{pH}$ によるコントロール}

$\mathrm{pH}$ 応答りポソームについて子研究が行わ机ている。 例えば, Nーパルミトイルホモシステインをリポソームの 構成成分の一つとしていれ，このホモシステインの $\mathrm{pH}$ による環化を利用した例がある15)。ホモシステインは酸 性状態では環状構造をとるため, リポソームの二分子膜 は不安定になり内包物は放出される。一方，アルカリ性 ではホモシステインは環状構造をとらないために膜は安 定であり，内包物は内部にトラップされたままになる。 このようにして，pH 変化でリポソームを不安定にする ことによって, 内包物の放出コントロールが可能にな る。 


\section{粧 技 誌 第23巻第 4 号 1990}

\section{3 光によるコントロール}

アゾ基のシスートランス互变異性化を利用して, 光に よる放出コントロールが行われている。アゾベンゼンの ようなアゾ基をるつ低分子を二分膜中に組及込むことに よって，紫外光を照射するとアゾ基はシス型をとり，脂 質間の間陌は広げられ，内包物は放出される。暗所また は $420 \mathrm{~nm}$ 以上の光ではアゾ基はトランス型をとり，脂 質間の間隔は狭くなり放出は抑制される。化精品に和い ても，紫外線に応答するリポソームを配合することによ って，より機能化することができるのではないかと考光 られる。

他の外部刺激としては, 磁場, 電場, 超音波などが研 究されている。

\section{8. 脂質膜被覆マイクロカプセル}

リポソームを調製後，長期間安定に保存する方法とし て，多糖類で被覆和よび脂質分子中に重合基を大れ高分 子化することが試みられていることはすでに述べたが， これに関連して，脂質膜被覆マイクロカプセルも研究さ れている16)。物理的，化学的に安定なマイクロカプセル とリポソームのもつ生体適合性の特性を利用しょうとす

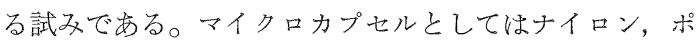
リスチレンなどが用いられて和り，その内部に薬物など を内包させる。マイクロカプセル自身の生体適合性は之 しく，また内包物が自由に透過できる空孔があるため， この久点をカバーするため脂質膜で外部を被覆する。こ の場合に招いても, 光, 熱, $\mathrm{pH}$ などの外部刺激応答機 能をもつリポソームを用いる試夕が行われている。

最近，河野，木村，今西ら ${ }^{17}$ は新しいタイプの $\mathrm{pH}$ 応 答性の脂質膜被覆マイクロカプセルを開発している。そ の方法は, ナイロンマイクロカプセルにヘリックス形成 能のあるポリペプチドをまず被覆し，さらに最外層を脂 質二分子膜でカバーする。このようなマイクロカプセル は $\mathrm{pH}$ 変化に応答して，中間層にあるポリペプチドがへ リックスーランダムコイル転移をする。ヘリックス状態 では最外層の脂質二分子膜は乱れることなく規則正しく 配列しているため，内包物は外部に透過しないが，ラン ダムコイルになると，規則正しく配列していた膜は乱れ て内包物は透過するようになる。リシン残基をもつポリ ペプチドでは，酸性領域でランダムコイル状になるた め, 内包物の透過は容易になるといら結果を得ている。

\section{9. おわりに}

本稿では, リポソームに関する最近の研究の流れを概 観した。リポソーム配合化粧品に括いても, 高度に機能 化されたリポソームの利用が，今後ますます盛ん度 のではないかと考觉られ。

\section{文献}

1）瀬崎 仁編 “ドラッグデリバリーシステム” (1986) 南江堂

2) 鈴木一成, 左近健一, フレグランスジャーナル, 15, 60 (1987)

3）坂野喜子，野沢義則，膜 (Membrane)，10, 235 (1985)

4) R.E. Pagano and J. N. Weinstein, Ann. Rev. Biophys. Bioeng., 7, 435 (1978)

5) 特開昭 60-152410

6) D.K. Struck, D. Hoekstra, and R.E. Pagano, Biochemistry, 20, 4093 (1981)

7) H. Ellens, J. Bentz, and F.C. Szoka, Biochemistry, 23, 1532 (1984)

8) H. Ellens, J. Bentz, and F.C. Szoka, Biochemistry, 24, 3099 (1985)

9) P.M. Brown and J.R. Silvius, Biochim. Biophys. Acta, 980, 181 (1989)

10）砂本順三，佐藤智典，日化，1989，161

11) 砂本順三，ファルマシア，21，1229 (1985)

12) J. Sunamoto, T. Sato, M. Hirota, K. Fukushima, K. Hiratani, and K. Hara, Biochim. Biophys. Acta, 898, 323 (1987)

13) K. Dorn, S. Kobayashi, and H. Ringsdorf, “人工細胞へのアプローチ”（国武，田伏，土田 編) p. 153 (1983) 化学同人

14) J.N. Weinstein, R.L. Magin, R.L. Cysyk, and D.S. Zaharko, Cancer Res., 40, 1388 (1980)

15) M.B. Yatvin, W.Kreutz, B.A. Horwitz, and M. Shinitzky, Science, 210, 1253 (1980)

16) Y. Okahata, Acc. Chem. Res., 19, 57 (1986)

17) K.Kono, S.Kimura, and Y.Imanishi, Polym. Prepr. Jpn., 37, 3535 (1988)

(平成 1 年 10 月 2 日受理) 